\title{
Sosialisasi Bahaya Narkoba dan Zat Aditif Pada Kader Posyandu Remaja di Lembaga Pembinaan Khusus Kelas 1 Medan
}

\author{
Cut Masyithah Thaib ${ }^{1}$, Jon Kennedy Marpaung ${ }^{2}$, Monica Suryani* \\ 1,3 Prodi S1 Farmasi, Universitas Sari Mutiara Indonesia, Medan, Indonesia \\ ${ }^{2}$ Prodi D3 Anafarma, Universitas Sari Mutiara Indonesia, Medan, Indonesia \\ *Coresponding Author: monicasuryani2@gmail.com \\ Dikirim: 09-02-2022; Direvisi: 12-02-2022; Diterima: 13-02-2022
}

\begin{abstract}
Abstrak: Penyalahgunaan narkoba merupakan masalah yang kompleks dan memiliki dimensi yang luas, baik dari sudut medik, psikiatrik, kesehatan jiwa, maupun psikososial. Penyalahgunaan Narkoba menimbulkan dampak antara lain, merusak hubungan kekeluargaan, menurunkan kemampuan belajar, ketidakmampuan untuk membedakan mana yang baik dan buruk, perubahan perilaku menjadi anti sosial, merosotnya produktivitas kerja, gangguan kesehatan, mempertinggi kecelakaan lalu lintas, kriminalitas dan tindak kekerasan lainnya, baik kuantitatif maupun kualitatif. Tujuan pengabdian masyarakat ini untuk memberikan informasi dan edukasi Bahaya Narkoba dan Zat Aditif Pada Kader Posyandu Remaja. Hasil kegiatan pelaksanaan program pengabdian masyarakat dalam bentuk memberikan edukasi dan sosialisasi Bahaya Narkoba dan Zat Aditif Pada Kader Posyandu Remaja. Kesimpulan kegiatan ini membawa dampak dan pengaruh yang baik terhadap pengetahuan masyarakat untuk menyadari bahaya narkoba dan zat aktif yang hanya tidak merugikan diri sendiri tetapi dapat merugikan keluarga dan orang lain. Sosialisasi terlaksana sesuai pelaksanaan dan rencana, mendapat sambutan yang baik dari Lembaga Pembinaan Khusus Kelas 1 Medan.
\end{abstract}

Kata Kunci: Sosialisasi Bahaya Narkoba; Zat Aditif; Kader Remaja

\begin{abstract}
Drug abuse is a complex problem and has broad dimensions, both from a medical, psychiatric, mental health, and psychosocial point of view. Drug abuse has an impact, among others, damaging family relationships, reducing learning abilities, inability to distinguish between good and bad, changes in behavior to become anti-social, decreases work productivity, health problems, increases traffic accidents, crime and other acts of violence, both quantitatively. As well as qualitative. The purpose of this community service is to provide information and education on the Dangers of Drugs and Additives to Youth Posyandu Cadres. The results of the community service program implementation activities in the form of providing education and socialization of the Dangers of Drugs and Additives to Youth Posyandu Cadres. The conclusion of this activity is that this activity has a good impact and influence on people's knowledge to realize the dangers of drugs and active substances which only do not harm themselves but can harm their families and others. The socialization was carried out according to the implementation and plan, received a good response from the Medan Class 1 Special Guidance Institute.
\end{abstract}

Keywords: Socialization of the Dangers of Drugs; Additive Substances; Adolescent Levels

\section{PENDAHULUAN}

Perkembangan penyalahgunaan dan peredaran gelap narkoba di dunia sungguh luar biasa dahsyat. Berdasarkan data dari Word Drugs Report yang dikeluarkan oleh United Nations Office on Drug and Crime (UNODC) menunjukkan bahwa setiap tahunnya negara-negara di seluruh dunia dibanjiri 1.000 ton heroin, 1.000 ton kokain, 
sejumlah besar ganja, Hashish dan Amphetamine Type Stimulants (ATS). Selain itu jumlah current users di seluruh dunia pada tahun 2005/2006 diperkirakan mencapai sekitar 200 juta orang dan pada tahun 2006/2007 meningkat menjadi 208 juta orang dan terus akan meningkat. Dengan fakta ini, maka diperkirakan tingkat pertumbuhan penyalahgunaan narkoba di dunia mencapai $4 \%$ per tahun. Kemudian diperkirakan antara 155 sampai dengan 250 juta orang ( $3,5 \mathrm{~s} / \mathrm{d}$ 5,7\% dari penduduk yang berumur 15-64 tahun) menggunakan narkoba minimal sekali dalam setahun (BNN, 2013).

Lingkup Asia Tenggara, semua negara ASEAN telah mengakui adanya masalah yang mereka hadapi terkait dengan penyalahgunaan narkoba. Asia tenggara memiliki potensi besar untuk menjadi lahan subur penyalahgunaan narkoba dikarenakan adanya segitiga emas penghasil dan penyalur gelap narkoba di wilayah ini yang terdiri dari Myanmar, Kamboja, dan Thailand yang memungkinkan distribusi produk narkotika melalui media transport darat, laut, maupun udara ke semua negara di wilayah ini, tak luput juga Indonesia (BNN, 2013).

Kasus penyalahgunaan narkoba meningkat dengan cepat. Meskipun pemerintah dan masyarakat telah melakukan berbagai upaya, penyalahgunaan narkoba terlihat begitu sulit diberantas. Penyalahgunaan narkoba di Demikian halnya di Indonesia, kasus penyalahgunaan narkoba meningkat dengan cepat. Meskipun pemerintah dan masyarakat telah melakukan berbagai upaya, penyalahgunaan narkoba terlihat begitu sulit diberantas. Indonesia telah sampai pada titik yang menghawatirkan. Berdasarkan data yang dihimpun Badan Narkotika Nasional (BNN), jumlah kasus narkoba meningkat dari sebanyak 3. 478 kasus pada tahun 2000 menjadi 8.401 pada tahun 2004, atau meningkat $28,9 \%$ pertahun. Berdasarkan hasil survei BNN bekerjasama dengan Pusat Penelitian Kesehatan Universitas Indonesia (UI) memperkirakan prevalensi penyalahgunaan narkoba pada tahun 2009 sebesar 1,99\% dari penduduk Indonesia berumur 10-59 tahun. Pada tahun 2010 prevalensi tersebut diproyeksikan naik menjadi 2,21\% dan tahun 2015 naik menjadi 2,8\% atau setara dengan 5,1-5,6\% juta orang (BNN, 2011).

Fenomena di atas jelas menggambarkan akan adanya bahaya bagi kelangsungan pembangunan nasional apabila generasi penerus bangsa menjadi rusak karena penyalahgunaan narkoba. Apabila seorang pelajar menyalahgunakan narkoba maka akan sangat merugikan bagi dirinya sendiri karena sering tertidur di kelas, tidak dapat mengikuti pelajaran dengan kontinu dan sering bolos sekolah, sehingga banyak penyalahguna narkoba menjadi putus sekolah dan akhirnya mereka merasa tidak punya harapan akan masa depan. Jika dibiarkan berlanjut penyalahguna narkoba akan menjadi beban keluarga yang sangat berat, dan berdampak kepada masyarakat dan negara (BNN, 2013; Dwitiyanti, 2019).

NAPZA (Narkotika, Psikotropika, dan Zat Adiktif lain) adalah bahan/ zat/ obat yang bila masuk ke dalam tubuh manusia akan mempengaruhi tubuh terutama otak/ susunan saraf pusat, sehingga menyebabkan gangguan kesehatan fisik, psikis, dan fungsi sosialnya karena terjadi kebiasaan, ketagihan (adiksi) serta ketergantungan (dependensi) terhadap NAPZA. Penyalahgunaan NAPZA adalah penggunaan salah satu atau beberapa jenis NAPZA secara berkala atau teratur diluar indikasi medis, sehingga menimbulkan gangguan kesehatan fisik, psikis dan gangguan fungsi sosial. NAPZA di sisi lain dapat menimbulkan ketergantungan apabila dipergunakan tanpa adanya pengendalian (Sholihah, 2014; Jaya dkk, 2021). 
Program rehabilitasi membantu para pecandu narkoba dalam penanggulangan narkoba, namun, tidak semua para pecandu narkoba memilih mengikuti program rehabiitasi. Pecandu narkotika dan korban penyalahgunaan narkotika wajib menjalani rehabilitasi medis atau rehabilitasi sosial di pusat rehabilitasi ketergantungan narkotika (Pantjalina, 2014; Lusiana, 2020).

HBM mengasumsikan bahwa keinginan seorang individu untuk melakukan tindakan pencegahan kesehatan tergantung pada lima komponen, yaitu perceived susceptibility (persepsi resiko/ kerentanan) terhadap penyakit tertentu, perceived severity (persepsi keparahan) penyakit, perceived benefits (persepsi manfaat) melakukan tindakan pencegahan, perceived barriers (persepsi hambatan) untuk melakukan tindakan pencegahan dan cues to action (panduan untuk bertindak) (Xianhong et al, 2016; Pradana, 2019).

Tujuan pengabdian kepada masyarakat ini adalah untuk melaksanakan Sosialisasi Bahaya Narkoba Dan Zat Aditif Pada Kader Posyandu Remaja di Lembaga Pembinaan Khusus Kelas 1 Medan.

\section{METODE PELAKSANAAN KEGIATAN}

\section{Waktu dan Tempat}

Pelaksanaan Sosialisasi Bahaya Narkoba dan Zat Aditif Pada Kader Posyandu Remaja dilaksanakan tanggal 14 Oktober 2021, di Lembaga Pembinaan Khusus Kelas 1 Medan.

\section{Langkah-Langkah Pelaksanaan}

1. Acara pembukaan membuka acara penyuluhan pemakaian obat yang benar untuk memberikan sambutan sekaligus penyemangat tanda peserta penyuluhan pemakaian obat yang benar yangdiwakili oleh salah satu panitia.

2. Dilaksaakan Pre test yang bertujuan untuk mengukur pengetahuan peserta.

3. Kemudian dilanjutkan oleh Tim Pembicara dalam memimpin kegiatan BLC (Building Learning Commitment) atau membangun kotmimen dalam pembelajaran untuk lebih memperkealkan diri masing-masing peserta.

4. Dilanjutkan dengan acara pokok yaitu presentasi/penjelasan materi-materi yang meliputi Bahaya Narkoba dan Zat Aditif

5. Dalam pemberian materi inti ataupun penujang fasilisator mengguakan metoda pembelajaran :

6. Ceramah
a. Tanya jawab
b. Diskusi
c. Seminar

7. Topik-topik yang di bahas dalam diskusi /seminar :

a. Pernilaian masalah kesehatan masyarakat

b. Penyuluhan pemakaian obat yang benar

8. Setelah selesai penyampain seluruh materi baik isi maupun penunjanng dengan berbagai metode pembalajaran maka dilanjutkan dengan pernilaian (post test) pada peserta, yang bertujuan untuk mengetahui sejauh mana peserta dapat menguasai materi yang di sampaikan oleh fasilator yang dilanjutkan dengan 
pembuatan rencana tindak lanjut dimana peserta di tuntut untuk merencanakan kegiatan di Lembaga Pembinaan Khusus Kelas 1 Medan.

9. Kegiatan pelatihan ditutup yang di lajutkan dengan doa oleh panitia.

\section{IMPLEMENTASI KEGIATAN DAN PEMBAHASAN}

Kegiatan penyuluhan kepada masyarakat Bahaya Narkoba dan Zat Aditif Pada Kader Posyandu Remaja. Kegiatan penyuluhan Bahaya Narkoba dan Zat Aditif Pada Kader Posyandu dilaksanakan di Lembaga Pembinaan Khusus Kelas 1 Medan. Kegiatan ini disambut baik oleh di Lembaga Pembinaan Khusus Kelas 1 Medan. Pelaksanaan kegiatan ini sangat direspon dengan sangat baik oleh masyarakat.

Pelaksanaan pengabdian masyarakat dalam bentuk penyuluhan dalam memberikan edukasi kepada masyarakat Bahaya Narkoba dan Zat Aditif Pada Kader Posyandu Remaja. Kegiatan penyuluhan ini yang bertujuan memberikan pengalaman dan meningkatkan pengetahuan mengenai bahaya Narkoba dan Zat Aditif Pada Kader Posyandu Remaja. Kegiatan ini dilakukan karena Penyalahgunaan Napza saat ini menjadi masalah yang semakin meluas dan telah menjadi keprihatinan berbagai pihak, banyak nilai kemanusiaan yang mulai luntur dari Napza. Apabila bahan atau zat ini masuk ke dalam tubuh maka akan mempengaruhi tubuh terutama susunan syaraf pusat atau otak sehingga jika disalahgunakan akan menyebabkan gangguan fisik, psikis/ jiwa dan terganggunya fungsi sosial seorang individu. Penanggulangan yang dilakukan terhadap Napza sudah dilakukan oleh berbagai pihak dengan banyak cara. Salah satu cara penanggulangannya adalah memberikan sistem pembinaan (Ridho, 2018).
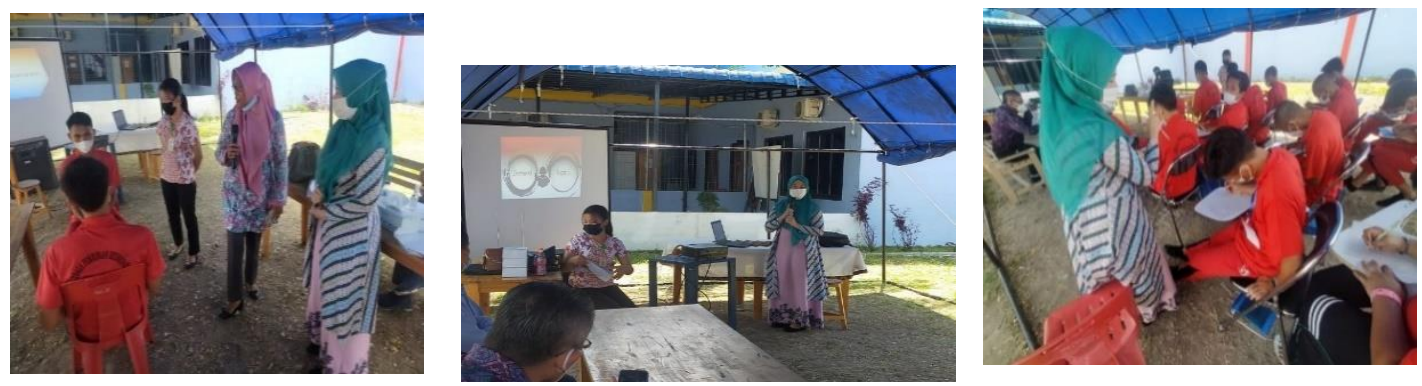

Gambar 1. Sosialisasi Bahaya Narkoba dan Zat Aditif

Hampir semua jenis NAPZA akan mengaktifkan satu sistem di otak yang mengatur rasa senang atau biasa disebut reward system dengan meningkatkan ketersediaan dopamin di otak, di mana dopamin merupakan suatu jenis neurotrasmitter yang bekerja mengontrol rasa senang. Jika penyalahguna terus menerus menggunakan NAPZA maka otak akan beradaptasi dengan keberadaan dopamine yang tinggi. Hal tersebut menyebabkan penggunaan NAPZA berusaha untuk menjaga agar fungsi dopamin dalam keadaan stabil atau berusaha menambah dosis NAPZA untuk mencapai dopamin yang tinggi, dan disertai dengan penggunaan yang dilakukan secara terus menerus atau kecanduan (Ikawati, 2016). Kalangan pelajar yang berada pada kelompok usia remaja memiliki emosi yang masih labil sehingga sangat rentan untuk menyalahgunakan NAPZA. Hal tersebut bisa dikarenakan beberapa hal antara lain rasa ingin tahu yang sangat besar, ikutikutan teman, rasa solidaritas grup yang kuat sampai dengan faktor keluarga yang kurang

@2022 Bima Abdi (https://jurnal.bimaberilmu.com/index.php/ba-jpm) 
perhatian. Anak remaja biasanya memiliki keinginan untuk mencari tahu sesuatu yang tidak diketahuinya (Simangunsong, 2015).

Adiktif merupakan sifat yang membuat pemakai memakai terus dan tidak dapat menghentikannya. Toleransi merupakan sifat narkotika, psikotropika dan bahan adiktif lainnya yang membuat tubuh pemakainya semakin lama semakin menyatu dengan narkoba dan menuntut dosis pemakaian terus menerus dan meningkat bahkan dengan penignkatan dosis yang sangat tinggi (Eleanora, 2011). Pada umumnya penanganan masalah-masalah psikologis yang mendasari munculnya adiksi belum sepenuhnya tertangani, terbukti ada mantan pecandu yang telah keluar dari rehabilitasi tetapi masih menyatakan mempunyai masalah dengan orang tua, dengan dirinya sendiri dan menyatakan belum mampu mengatasi pengaruh lingkungan (Adiyanti \& Yuniarti, 2015).

\section{KESIMPULAN}

Berdasarkan hasil kegiatan penyuluhan kepada masyarakat Bahaya Narkoba dan Zat Aditif Pada Kader Posyandu Remaja. Maka dapat disimpulkan bahwa kegiatan ini membawa dampak dan pengaruh yang baik terhadap pengetahuan masyarakat untuk menyadari bahaya narkoba dan zat aktif yang hanya tidak merugikan diri sendiri tetapi dapat merugikan keluarga dan orang lain.

Saran untuk pengabdian masyarakat selanjutnya untuk lebih sering dilakukan dikarenakan saat ini banyak masyarakat yang belum mengetahui bahaya narkoba dan zat aktif bagi kesehatan.

\section{UCAPAN TERIMA KASIH}

Kami dari Tim Pengabdian kepada masyarakat mengucapkan terimakasih kepada Pimpinan dan Kader Posyandu Remaja Lembaga Pembinaan Khusus Kelas 1 Medan, yang telah membantu dalam memberikan izin sehingga kegiatan ini berjalan dengan baik dan seluruh masyarakat yang ikut berpartisipasi, waktu dan kesempatan kepada kami untuk melakukan pengabdian masyarakat ini.

\section{DAFTAR PUSTAKA}

Adiyanti, M. G.,dan Yuniarti, K. W. (2015). Memaknai kondisi residen therapeutic community. Laporan Penelitian. Yogyakarta: Fakultas Psikologi Universitas Gadjah Mada.

BNN. (2011). Pencegahan Penyalahgunaan Narkoba Bagi Remaja. Jakarta

BNN. (2013). Bahaya Penyalahgunaan Narkoba dan Penanggulangannya. Medan

Dwitiyanti, D., Efendi, K., \& Supandi, S. (2019). Penyuluhan Tentang Bahaya Penyalahgunaan Narkotik, Psikotropika dan Zat Aditif Bagi Siswa Siswi SMA dan SMK Mutiara 17 Agustus. SEMAR (Jurnal Ilmu Pengetahuan, Teknologi, dan Seni bagi Masyarakat), 8(1), 40-43.

Eleanora, F N. (2011). Bahaya Penyalahgunaan Narkoba Serta Usaha Pencegahan dan Penanggulangannya (Suatu Tinjauan Teoritis). Jurnal Hukum. Halaman. 439-452. 
Fitri, M. (2014). Sosialisasi dan penyuluhan narkoba. Asian Journal of Innovation and Entrepreneurship, 3(2), 72-76.

Ikawati, Z. (2016). Mengapa Orang Bisa Kecanduan NAPZA. Tribun Jogja pp.13

Jaya, I., Tanzil, M., Ronaldo, M., \& Rsyadi, I. (2021). Sosialisasi Bahaya Penyalagunaan Narkoba Bagi Generasi Muda Desa Sungai Rengit Kecamatan Talang Kelapa Kabupaten Banyu Asin. suluhabdi, 3(1), 5-11.

Lusiana, E. (2020). Upaya Mewujudkan Generasi Muda Bebas Narkoba melalui Sosialisasi dan Skrining Narkoba di SMP N 9 Palembang. Jurnal Pengabdian Sriwijaya, 8(2), 1022-1027.

Pantjalina. E.R. Syafar, M. Natsir. M. (2013). Faktor Mempengaruhi Perilaku Pecandu Penyalahgunaan Napza Pada Masa Pemulihan di Rumah Sakit Jiwa Daerah Samarinda. Jurnal Keperawatan Jiwa, 1-11.

Pradana, D. A., Amelia, D., Shavera, F., \& Purnamasari, O. (2019, December). Sosialisasi Jenis dan Bahaya Narkoba bagi Kesehatan pada Ikatan Pemuda Waru Rw 05 Pamulang Barat, Tangerang Selatan. In Prosiding Seminar Nasional Pengabdian Masyarakat LPPM UMJ.

Ridho, H. (2018). Bimbingan Konseling Spiritual Terhadap Pasien Rehabilitasi Napza Universitas Islam Negeri (UIN) Kalijaga Yogyakarta.

Sholihah, Q. (2014). Efektivitas Program P4gn Terhadap Pencegahan Penyalahgunaan NAPZA. Jurnal Kesehatan Masyarakat. Program Studi Kesehatan Masyarakat Fakultas Kedokteran Universitas Lambung Mangkurat.

Simangunsong, J. (2015). Penyalahgunaan Narkoba di Kalangan Remaja. Skripsi: Universitas Maritim Raja Ali Haji Tanjung Pinang.

Xianhong, L. Yunxiao, L. Honghong, W. Guoping, H \& William, A.B., (2016). The Health Belief Model: A Qualitative Study to Understand High-Risk Sexual Behavior in Chinese Men Who Have Sex With Men. JANAC. Halaman 27, 6776. 